\title{
Effects of Human Low-Density Lipoproteins on Superoxide Production by Formyl-Methionyl-Leucyl-Phenylalanine Activated Polymorphonuclear Leukocytes
}

\author{
Christine Bonneau ${ }^{1}$, Rémy Couderc ${ }^{1}$, Michéle Tissot ${ }^{1}$, Anne Athias $^{2}$, Monique Roch-Arveiller $^{1}$ and \\ Jean Paul Giroud ${ }^{1}$ \\ 1 Laboratoire de Pharmacologie, Unité CNRS 15-35, Hôpital Cochin, Paris, France \\ ${ }^{2}$ Laboratoire de Biochimie des Lipoprotéines, Hôpital du Bocage, Dijon, France
}

Summary: Neutrophils play a major role in the host defence by producing reactive oxygen species. These products are liberated by activated cells and are known to cause endothelial cell injury and damage. The present study shows that low-density lipoproteins increase superoxide anion production by twofold in polymorphonuclear leukocytes stimulated by formyl-Met-Leu-Phe in vitro. Moreover, LDL induced a large increase in phosphoinositides and cytosolic-free calcium. Data from experiments performed on neutrophils treated with pertussis toxin, staurosporine, propranolol or niflumic acid suggest that modulation of phospholipase $\mathrm{D}$ and $\mathrm{A}_{2}$ activities could be involved in the modification by LDL of leukocyte response to formyl-Met-Leu-Phe. LDL lipid moiety could play a key role in their action on polymorphonuclear functions because cholesterol was exchanged between lipoproteins and cells that can modify membrane fluidity and interact with the formyl-Met-Leu-Phe receptor.

\section{Introduction}

Dyslipoproteinaemia, demonstrating increased blood lipoprotein concentrations, hypertension and tabagism, is often associated with accelerated atherogenesis mechanisms $(1,2)$. Increased lipoprotein concentrations, and especially high low-density lipoprotein (LDL) concentrations, could modify polymorphonuclear leukocyte (PMN) functions. Some authors have reported the enhanced oxidative metabolism of polymorphonuclear neutrophils isolated from hyperlipoproteinaemic subjects and an inhibition of polymorphonuclear neutrophil phagocytosis following their treatment with LDL in vitro $(3,4)$.

In a previous study, we demonstrated that LDL stimulates superoxide $\left(\mathrm{O}_{2}^{-}\right)$generation by human polymorphonuclear neutrophil in vitro (5). This effect is concentration dependent and might mediate venous endothelial structure injury by arachidonic acid metabolites, proteolytic enzymes and reactive oxygen species released by activated polymorphonuclear neutrophils $(6-10)$. Moreover, they might enhance LDL oxidation and contribute to the formation of foam cells mainly implicated in the atherogenic process $(11-13)$.

The oxidative burst results from the assembly and activation of the NADPH oxidase, a transmembrane electron transport chain which reduces oxygen to superoxide $(14,15)$. This $\left(\mathrm{O}_{2}^{-}\right.$generation is initiated in neutrophils by a variety of agonists (16). Among them is the formyl-Methionyl-Leucyl-Phenylalanine, a tripep- tide analogous to bacterial wall constituents, and currently being used for in vitro experiments. Polymorphonuclear neutrophil activation by formyl-Met-Leu-Phe triggers a cascade of tightly controlled biochemical events leading to an oxidative burst (17-19). The first step consists of the ligand binding to specific cell surface receptors. Among them is the formyl-Met-Leu-Phe receptor which is well-characterized and coupled to cellular responses through a pertussis toxin-inhibitable $G$ protein (20). Three phospholipases are mainly involved at different steps of neutrophil activation; phospholipase $\mathrm{C}$, phospholipase $\mathrm{A}_{2}$ and phospholipase $\mathrm{D}$. Hydrolysis of membrane phospholipids leads to the formation of numerous bioactive lipids. These pathways were implicated in the signal transduction of polymorphonuclear neutrophil activated by formyl-Met-Leu-Phe $(18,21)$.

In order to clarify LDL effects of formyl-Met-Leu-Pheinduced polymorphonuclear neutrophil oxidative burst, we investigated in vitro the action of pharmacological tools on some steps of transduction leading to the oxidative burst of polymorphonuclear neutrophil.

\section{Materials and Methods}

Reagents

Pertussis toxin (lot 72H-0641-1), staurosporine, propranolol, niflumic acid, and formyl-Met-Leu-Phe were purchased from Sigma Chemical Co. (Saint-Louis MO, USA).

Stock solutions of formyl-Met-Leu-Phe $(1 \mathrm{mmol} / \mathrm{l})$ and staurosporine $(1 \mathrm{mmol} / \mathrm{l})$ were prepared in dimethyl sulphoxide and stored at $-20^{\circ} \mathrm{C}$. 
Stock solution of propranolol $(50 \mathrm{mmol} / \mathrm{l})$ was prepared in phosphate buffered saline without $\mathrm{Ca}^{2+}$ and $\mathrm{Mg}^{2+}$ and stored at $-20^{\circ} \mathrm{C}$.

Dilutions of stock solutions were made in phosphate buffered saline for each experiment.

\section{Lipoprotein isolation}

LDL $(1.030<\mathrm{d}<1.050 \mathrm{~kg} / \mathrm{l})$ was prepared from the serum of normolipaemic subjects $(3.5 \mathrm{mmol} / 1<$ total cholesterol $<6.5$ $\mathrm{mmol} / \mathrm{l}$ and triacylglyerols $<1.0 \mathrm{mmol} / \mathrm{l})$ in the presence of ethylenediaminetetraacetic acid $(2.69 \mu \mathrm{mol} / \mathrm{l})$ and phenylmethylsulphonyl fluoride $(0.1 \mathrm{mmol} / \mathrm{l})$ to prevent both action of lipolytic enzymes and endogenous proteases and to avoid oxidation. Isolation of LDL was achieved through two successive ultracentrifugation steps at $100000 \mathrm{~g}$ for 18 hours at $4^{\circ} \mathrm{C}$. It was then dialyzed exhaustively against the phosphate buffer and stored for less than five days under nitrogen at $4{ }^{\circ} \mathrm{C}$ after sterilization by filtration $(0.22$ $\mu \mathrm{m}$ Millipore). The purity of the LDL fraction was assayed by SDS polyacrylamide gel electrophoresis. Since the main constituent of LDL is cholesterol, LDL concentration was expressed as LDL cholesterol in $\mathrm{mmol} / \mathrm{l}$.

\section{Cell preparation}

The cells were isolated from heparinized (10000 U/l) peripheral blood of healthy volunteers from the laboratory population, by successive use of Ficoll-Hypaque and polyvinylalcohol (22). After isolation, the cells were put in a phosphate buffered solution for determination of superoxide generation and viability was assessed through a trypan blue exclusion test.

\section{Superoxide production}

Superoxide production was measured in terms of ferricytochrome $\mathrm{c}$ reduction as previously described $(5,23)$. The stimulating agent was formyl-Methionyl-Leucyl-Phenylalanine $100 \mathrm{nmol} / \mathrm{l}$. The results were expressed as $\mathrm{O}_{2}^{-}$release in mmol/10 $10^{6}$ cells.

\section{Phospholipid turnover analysis}

\section{Polymorphonuclear neutrophil labelling}

After isolation, polymorphonuclear neutrophil cell count was adjusted to $10^{10} / 1$ in Hank's balanced salt solution containing 20 $\mathrm{mmol} / 1$ Hepes, $\mathrm{pH}=7.4$, supplemented with $250 \mathrm{mg} / 1$ bovine serum albumin as previously described (24). Cells were labelled with $7.4 \mathrm{GBq} / 1(200 \mathrm{mCi} / \mathrm{l})$ of $m y o-\left[2-{ }^{3} \mathrm{H}\right]$ inositol and incubated for $16-20 \mathrm{~h}$ at $37^{\circ} \mathrm{C}$ with gentle shaking.

At the end of incubation, cells were washed three times, counted and put in the same Hank's solution, supplemented with $1 \mathrm{~g} / 1$ bovine serum albumin and $10 \mathrm{mmol} / \mathrm{l} \mathrm{LiCl}$ (for inhibiting the enzymes of inositol phosphate dephosphorylation). Cells were adjusted to a concentration of $10^{7}$ cells per $600 \mu$ laliquots and incubated for $10 \mathrm{~min}$ at $37^{\circ} \mathrm{C}$ before the stimulation.

\section{Polymorphonuclear neutrophil stimulation}

Stimulating agents were applied to aliquots tested in duplicate, as follows:

- phosphate buffered saline for $15 \mathrm{~s}$ (controls)

- formyl-Met-Leu-Phe from $10^{-9}$ to $10^{-6} \mathrm{~mol} / 1$ for $15 \mathrm{~s}$

- LDL (2.5 mmol/1) for $5 \mathrm{~min}$

- LDL $(2.5 \mathrm{mmol} / \mathrm{l})$ for $5 \mathrm{~min}$ before the addition of formyl-MetLeu-Phe for $15 \mathrm{~s}$.

The reaction was stopped by addition of perchloric acid, followed by three cycles of freezing-thawing.

After centrifugation, the hydrosoluble perchloric acid precipitation supernatants containing inositol phosphates were diluted and neutralized. The inositol lipids were extracted from the perchloric acid insoluble pellets, dried and deacylated by alkaline hydrolysis as described by Creba et al. (25) and Poggioli et al. (26). The $\left[{ }^{3} \mathrm{H}\right]$ inositol phosphates and $\left[{ }^{3} \mathrm{H}\right]$ glycerophosphoryl esters were then separated by anion-exchange chromatography on Dowex AG1-X8 columns using the buffer system described by Downes et al. (27) and Berridge et al. (28).

\section{Cytosolic-free calcium concentrations}

Changes in cytosolic free calcium concentration were measured in polymorphonuclear neutrophil loaded with $1 \mu \mathrm{mol} / 1$ Fura $2 / \mathrm{AM}$ at $37^{\circ} \mathrm{C}$ for $45 \mathrm{~min}(29,30)$. Cells were then washed and suspended in $10 \mathrm{mmol} / 1 \mathrm{HEPES} /$ Hank's balanced salt solution. Fura 2 fluorescence assays were performed with aliquots of $5 \times 10^{6}$ polymorphonuclear neutrophil in $2 \mathrm{ml}$ Hank's balanced salt solution, using a fluorimeter (Jobin Yvon 3D, France) equipped with a thermally controlled cuvette holder and a magnetic stirrer. Various concentrations of LDL were tested: 0.01 to $5 \mathrm{mmol} / 1$ cholesterol. Excitation and emission wavelengths for Fura 2 fluorescence assays were 340 and $510 \mathrm{~nm}$, respectively. Cytosolic calcium concentrations were calculated as described (30).

Intracellular level of polymorphonuclear neutrophil cholesterol

Polymorphonuclear neutrophils were preincubated in duplicate at $37^{\circ} \mathrm{C}$ for $5 \mathrm{~min}$ and placed in contact with increasing concentrations of LDL for $15 \mathrm{~min}$. Superoxide generation was measured in half of the tubes and cellular cholesterol content was measured in the other. In these tubes, ferricytochrome $c$ was omitted. After stopping the reaction in an ice-water bath, the cells were washed three times in phosphate buffered saline before freezing.

After lipid extraction from neutrophils, cellular cholesterol measurement was performed by gas chromatography coupled with mass spectrometry. This measurement was performed in the Laboratoire de Biochimie des Lipoprotéines de Dijon (Service du Pr Gambert).

\section{Statistical analysis}

The Mann-Whitney's test and the Wilcoxon's test were used for the comparison of unpaired and paired quantitative variables.

\section{Results}

After polymorphonuclear neutrophil preincubation for $5 \mathrm{~min}$ at $37^{\circ} \mathrm{C}$ with buffer or LDL, superoxide production was assayed over the next $5 \mathrm{~min}$ in the presence of formyl-Met-Leu-Phe $100 \mathrm{nmol} / \mathrm{l}$.

In the presence of LDL, formyl-Met-Leu-Phe-induced stimulation was increased twofold (Wilcoxon's test: $\mathrm{p}$ 50.01) (control: $\mathrm{O}_{2}^{-} 6.72 \pm 1.65 \mathrm{nmol} / 10^{6}$ cells; with $\mathrm{LDL}$ at $2.5 \mathrm{mmol} / \mathrm{l}: \mathrm{O}_{2}^{-} 14.92 \pm 2.19 \mathrm{nmol} / 10^{6}$ cells; with $\mathrm{LDL}$ at $5 \mathrm{mmol} / \mathrm{l}: \mathrm{O}_{2}^{-} 16.59 \pm 2.18 \mathrm{nmol} /$ $10^{6}$ cells; means $\pm \mathrm{SEM}, \mathrm{n}=9$ ).

\section{Pertussis toxin action}

Preincubation with pertussis toxin $\left(1 \mu \mathrm{g}\right.$ for $2 \times 10^{7}$ cells) drastically impaired polymorphonuclear neutrophil response by ADP-ribosylation of G-protein (31). There was a variability in the activity of pertussis toxin depending on the batch purchased, but the maximal effect was observed with polymorphonuclear neutrophil treated for $2 \mathrm{~h}$ in Hank's solution under shaking, as previously described by Gabig et al. (32) and Omann et al. 
(33). After centrifugation, cells were washed before their stimulation by formyl-Met-Leu-Phe with or without LDL. The cells' response to formyl-Met-Leu-Phe was inhibited after pertussis toxin treatment, in the absence (polymorphonuclear neutrophils + formyl-Met-LeuPhe: $\mathrm{O}_{2}^{-} 14.37 \pm 0.83 \mathrm{nmol} / 10^{6}$ cells; polymorphonuclear neutrophils + pertussis toxin + formyl-Met-LeuPhe: $\mathrm{O}_{2}^{-} 3.28 \pm 1.38 \mathrm{nmol} / 10^{6}$ cells; means $\pm \mathrm{SEM}$, $\mathrm{n}=3$ ) or in the presence of LDL (polymorphonuclear neutrophils + LDL + formyl-Met-Leu-Phe: $\mathrm{O}_{2}^{-} 18.45$ $\pm 0.67 \mathrm{nmol} / 10^{6}$ cells; polymorphonuclear neutrophils + pertussis toxin + LDL + formyl-Met-Leu-Phe: $\mathrm{O}_{2}^{-}$ $3.72 \pm 1.44 \mathrm{nmol} / 10^{6}$ cells).

\section{Effects of LDL on phosphatidyl turnover}

Polymorphonuclear neutrophil incubation with LDL at a concentration of $2.5 \mathrm{mmol} / 1$ induced a large increase in phosphoinositides, and particularly in phosphatidylinositol 4,5-bisphosphate along with inositol 1,4,5-trisphosphate (fig. 1). Polymorphonuclear neutrophil incubation with formyl-Met-Leu-Phe induced, as expected, an activation of phosphatidylinositol 4,5-bisphosphate breakdown and formation of inositol 1,4,5-trisphosphate.
Stimulation of polymorphonuclear neutrophils by formyl-Met-Leu-Phe in the presence of LDL also led to an increase of phosphatidylinositol 4,5-bisphosphate in all the LDL or formyl-Met-Leu-Phe concentrations used (tab. 1).

\section{Effect of LDL on calcium mobilization}

The intracellular $\mathrm{Ca}^{2+}$ mobilization, measured as Fura 2 fluorescence intensity, increased with LDL concentrations (fig. 2). At the lowest LDL concentration, the kinetics were similar to those obtained by formyl-MetLeu-Phe stimulation. At LDL concentrations above 0.5 $\mathrm{mmol} / \mathrm{l}$ cholesterol, kinetics were the same as those obtained after polymorphonuclear neutrophil stimulation by a particular agent, such as opsonized zymosan. Bovine albumin at concentrations from 0.1 to $1.0 \mathrm{mg} / \mathrm{lin}$ duced less than $1 / 10$ of the increase in Fura 2 fluorescence intensity induced by LDL at respective protein concentrations.

\section{Staurosporine effect}

At a concentration of $100 \mathrm{nmol} / 1$, staurosporine showed a potentiation of formyl-Met-Leu-Phe-induced polymor-
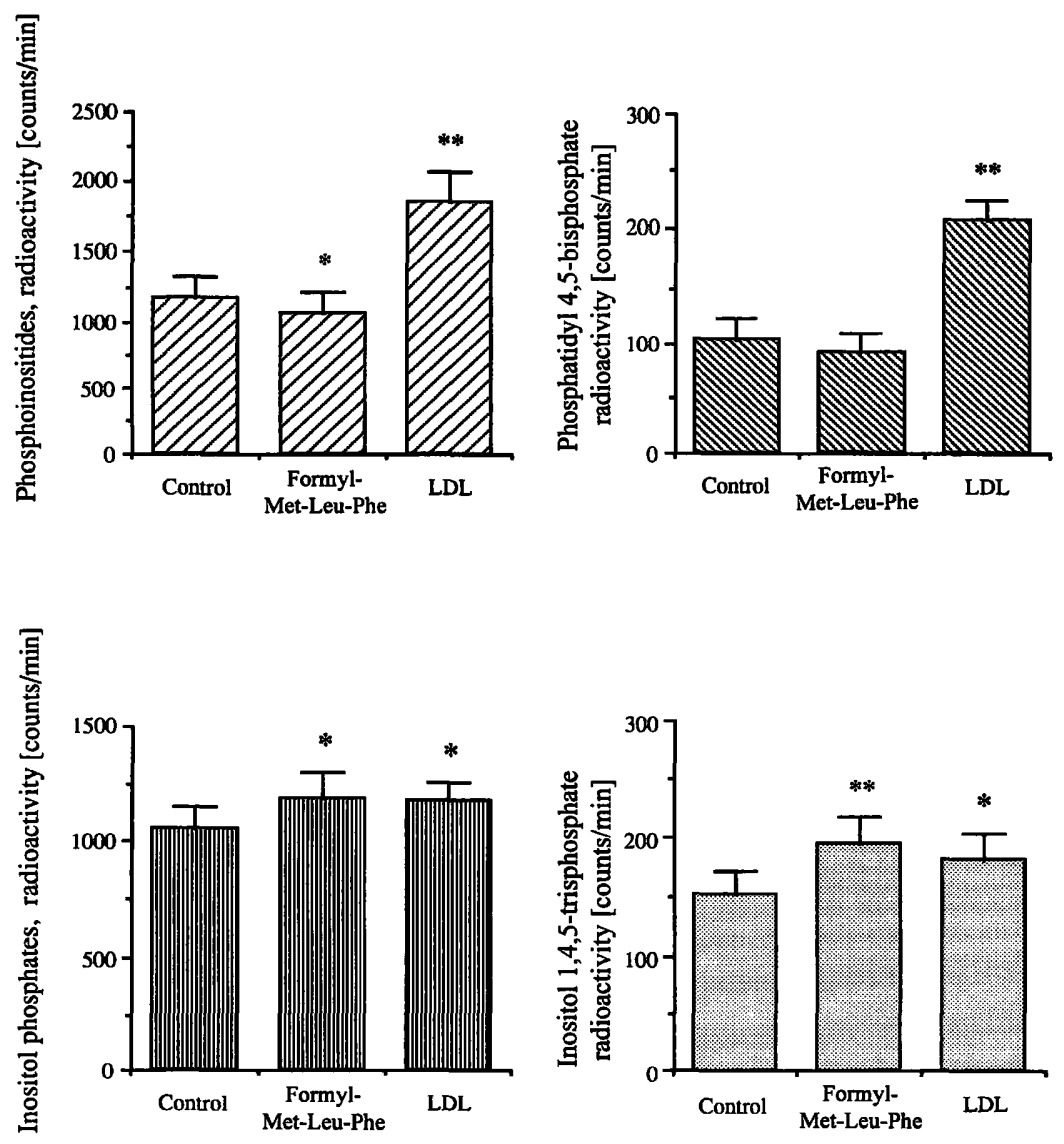

Fig. 1 Variation of phosphoinositides and inositol phosphates of polymorphonuclear neutrophils stimulated with formyl-Met-Leu-Phe or LDL. Mean \pm SEM

Wilcoxon's test for a paired series $(\mathrm{n}=10)$

* significantly different from control $\mathrm{p} \leq 0.05$

** significantly different from control $\mathrm{p} \leq 0.01$ 
Tab. 1 Effects of LDL on polymorphonuclear neutrophil stimulation by formyl-Met-Leu-Phe. Radioactivity was expressed in counts per minute

\begin{tabular}{|c|c|c|c|c|c|}
\hline \multirow{2}{*}{$\begin{array}{l}\mathrm{LDL} \\
(\mathrm{mmol} / \mathrm{l})\end{array}$} & \multirow{2}{*}{$\begin{array}{l}\text { Formyl-Met- } \\
\text { Leu-Phe } \\
(\mathrm{mmol} / \mathrm{l})\end{array}$} & \multicolumn{2}{|c|}{ Phosphatidylinositol 4,5-bisphosphate } & \multicolumn{2}{|c|}{ Inositol 1,4,5-trisphosphate } \\
\hline & & $\begin{array}{l}\text { Formyl-Met- } \\
\text { Leu-Phe } \\
\text { (counts/min) }\end{array}$ & $\begin{array}{l}\text { LDL + formyl- } \\
\text { Met-Leu-Phe } \\
\text { (counts/min) }\end{array}$ & $\begin{array}{l}\text { Formyl-Met- } \\
\text { Leu-Phe } \\
\text { (counts/min) }\end{array}$ & $\begin{array}{l}\text { LDL + formyl- } \\
\text { Met-Leu-Phe } \\
\text { (counts/min) }\end{array}$ \\
\hline 2.5 & $10^{-6}$ & 29 & 65 & 124 & 70 \\
\hline 2.5 & $10^{-6}$ & 167 & 292 & 164 & 170 \\
\hline 2.5 & $10^{-6}$ & 70 & 263 & 251 & 202 \\
\hline 5.0 & $10^{-6}$ & 33 & 136 & 168 & 136 \\
\hline 5.0 & $10^{-6}$ & 163 & 344 & 167 & 154 \\
\hline 2.5 & $10^{-7}$ & 77 & 200 & 241 & 220 \\
\hline 5.0 & $10^{-9}$ & 159 & 340 & 137 & 110 \\
\hline
\end{tabular}

phonuclear neutrophil stimulation (polymorphonuclear neutrophils + formyl-Met-Leu-Phe: $\mathrm{O}_{2}^{-} 2.58 \pm 0.92$ $\mathrm{nmol} / 10^{6}$ cells; polymorphonuclear neutrophils + staurosporine + formyl-Met-Leu-Phe: $\mathrm{O}_{2}^{--} 6.37 \pm 2.06$ $\mathrm{nmol} / 10^{6}$ cells; means $\pm \mathrm{SEM}, \mathrm{n}=3$ ).

Staurosporine did not significantly modify the LDL effect on the polymorphonuclear neutrophil response to formyl-Met-Leu-Phe (polymorphonuclear neutrophils + LDL + formyl-Met-Leu-Phe: $\mathrm{O}_{2}^{-} 8.12 \pm 1.91 \mathrm{nmol} / 10^{6}$ cells; polymorphonuclear neutrophils + staurosporine + $\mathrm{LDL}+$ formyl-Met-Leu-Phe: $\mathrm{O}_{2}^{-} 8.87 \pm 2.29 \mathrm{nmol} /$ $10^{6}$ cells).

\section{Propranolol effect}

Polymorphonuclear neutrophil preincubation for $5 \mathrm{~min}$ at $37^{\circ} \mathrm{C}$ with phosphate buffer or with various concen- trations of propranolol, ranging from $0.05 \mathrm{mmol} / 1$ to $5 \mathrm{mmol} / \mathrm{l}$, was performed before the polymorphonuclear neutrophil stimulation with LDL, formyl-Met-Leu-Phe or LDL + formyl-Met-Leu-Phe.

Propanolol exerted a potent stimulating effect at a concentration of $0.5 \mathrm{mmol} / 1$ but an inhibiting effect at the highest concentration $(5 \mathrm{mmol} / \mathrm{l})$.

LDL added their proper effect to that exerted by formylMet-Leu-Phe (fig. 3a).

\section{Niflumic acid effect}

Niflumic acid had no effect on polymorphonuclear neutrophil stimulation by LDL. When the cells were preincubated for $5 \mathrm{~min}$ at $37^{\circ} \mathrm{C}$ with various concentrations of niflumic acid $(88.6 \mu \mathrm{mol} / 1,443 \mu \mathrm{mol} / 1,886 \mu \mathrm{mol} / 1$,

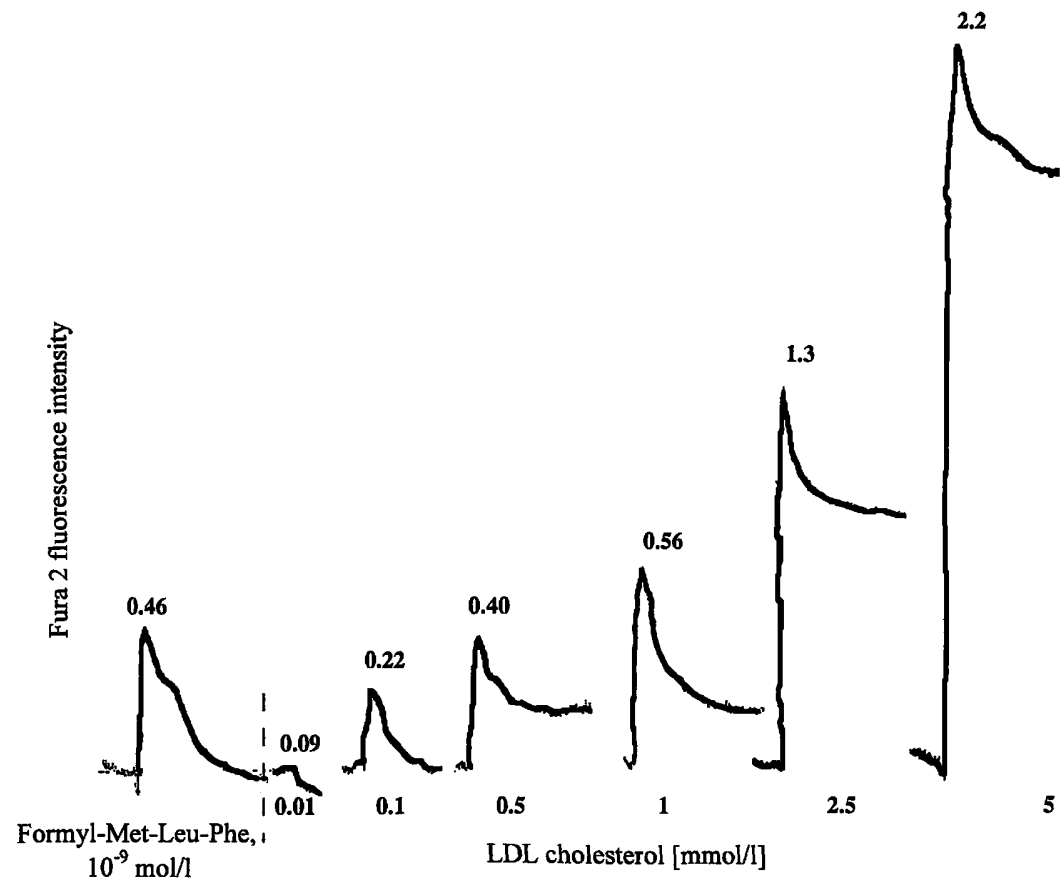

Fig. 2 Effect of LDL on cytosolic-free calcium concentration in polymorphonuclear neutrophils. Calcium concentration stated above the peaks was calculated from Fura 2 fluorescence intensity using the formula: $\left[\mathrm{Ca}^{2+}\right] \mathrm{nmol} / 1=224\left(\mathrm{~F}-\mathrm{F}_{\min }\right) /\left(\mathrm{F}_{\max }-\mathrm{F}\right)$ where $F_{\min }$ and $F_{\max }$ were the fluorescence intensity measured on unstimulated and on Triton X-100 treated polymorphonuclear neutrophils respectively. A representative experiment out of three is shown. 

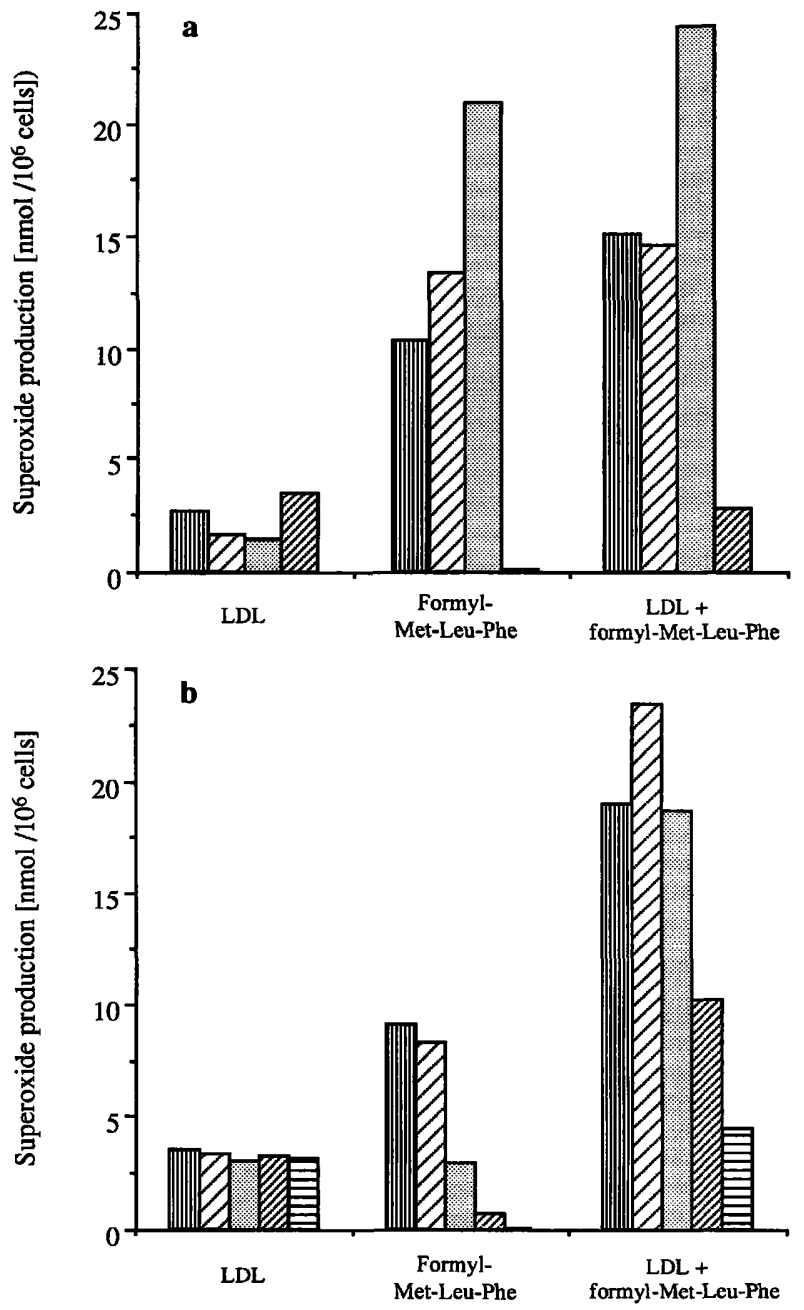

Fig. 3 Effect of propranolol (a) and niflumic acid (b) on polymorphonuclear neutrophil stimulation by formyl-Met-Leu-Phe and LDL.

Concentrations of propranolol used:

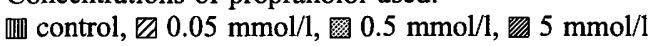

Concentrations of niflumic acid used:

血 control, $\square 88.6 \mu \mathrm{mol} / 1$, $0.5 \mathrm{mmol} / 1,2886 \mu \mathrm{mol} / 1$, 目 $1772 \mu \mathrm{mol} / 1$

Result of one representative experiment

$1772 \mu \mathrm{mol} / \mathrm{l})$ before the addition of formyl-Met-LeuPhe, an inhibiting effect was observed for concentrations higher than $88.6 \mu \mathrm{mol} / \mathrm{l}$. LDL potentiated the formylMet-Leu-Phe stimulating effect and added their proper stimulating effect to the response of control cells incubated in phosphate buffered saline (fig. 3b).

\section{Intracellular cholesterol content}

In the presence of LDL $(0.25-1 \mathrm{mmol} / 1$ cholesterol) a concentration-dependent increase of polymorphonuclear neutrophil cholesterol content was observed (MannWhitney test: $\mathrm{p} \leq 0.05$ ) (fig. 4).

\section{Discussion}

This study has shown that LDL, at physiological concentrations, interacts with polymorphonuclear neutrophil stimulation either directly by its own stimulating effect or indirectly by modification of the response to formylMet-Leu-Phe.

In previous work (5), a slight enhancement of the binding of formyl-Met-Leu-Phe to its specific membrane receptors was observed in the presence of LDL which may induce an increase in $\mathrm{O}_{2}^{-}$released in response to formyl-Met-Leu-Phe. Because LDL did not interfere with pertussis toxin inhibitable $G$ proteins, they also might have a "priming" effect which can potentiate the NADPH oxidase stimulation by formyl-Met-Leu-Phe (34) rather than increase the number or affinity of the formyl-Met-Leu-Phe receptors.

Phospholipase $\mathrm{C}$ activity was investigated by means of inositol phosphate measurement and a phosphoinositide metabolism study. We observed a highly significant increase of phosphatidylinositol 4,5-bisphosphate content which could not be due to an accelerated inositol turnover because dephosphorylating enzymes were inhibited by the lithium added to the incubation buffer. However, it is possible that tritiated inositol, in excess in the cell medium, conjugated to CMP-activated phosphatidic acid was able to replenish membrane stocks of phosphatidyl inositol (phosphates). This phenomenon might be due to phospholipase $\mathrm{D}$ activation by LDL, leading to an increased generation of phosphatidic acid. This activation may be greater than that of phospholipase $\mathrm{C}$ inducing a relatively weak enhancement of inositol 1,4,5-trisphosphate release. Inositol 1,4,5-trisphosphate is released into the cytosol, binds to specific receptors on intracellular $\mathrm{Ca}^{2+}$ storage organelles and induces the release of calcium. In our study, the intracellular calcium mobilization, measured as Fura 2 fluorescence intensity, increased with LDL concentrations. However at LDL cholesterol concentrations above

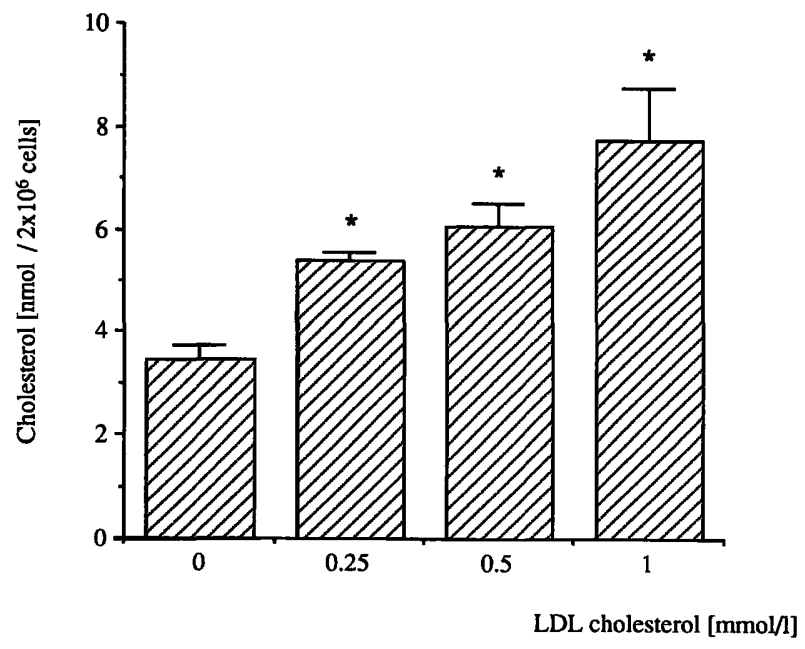

Fig. 4 Cellular cholesterol content of polymorphonuclear neutrophils after contact of $15 \mathrm{~min}$ with LDL at different concentrations. Mean \pm SEM; one experiment in triplicate

Mann-Whitney's test for non-paired values

* significantly different from control $(p \leq 0.05)$ 
$0.5 \mathrm{mmo} / \mathrm{l}$, Fura 2 fluorescence was sustained even in an incubation medium without calcium and in the presence of EGTA (data not shown). These data suggest that the calcium efflux could be decreased by LDL. To the best of our knowledge, there is no previous study on the effect of LDL on polymorphonuclear neutrophil phosphoinositide metabolism. However Block et al. (35) have already described a stimulation of the phosphatidylinositol cycle by LDL in human platelets, lymphocytes and fibroblasts.

Protein kinase $\mathrm{C}$, a phospholipid/ $\mathrm{Ca}^{2+}$-dependent kinase, is a key enzyme in the regulation of intracellular signal transduction. Staurosporine, an alkaloid extracted from Streptomyces, was described by Tamaoki et al. (36) as a protein kinase $\mathrm{C}$ inhibitor. These authors have suggested that staurosporine interacts directly with protein kinase $\mathrm{C}$ and this hypothesis has been corroborated by Nakadate et al. (37) who have shown that staurosporine interacts at the active site of the catalytic fragment of protein kinase C. Staurosporine is one of the most potent inhibitors, active at nanomolar concentrations, but demonstrates similar affinities for protein kinase C, tyrosine kinases and c-AMP-dependent protein kinase (38, 39). In our previous experiments, polymorphonuclear neutrophil stimulation by phorbol myristate acetate was inhibited $90 \%$ by staurosporine, $100 \mathrm{nmol} / 1$. However, the effect of LDL on polymorphonuclear neutrophil does not seem to be directly and exclusively protein kinase C-dependent because in the present study it was not inhibited by staurosporine.

Nevertheless, staurosporine exerts several effects on polymorphonuclear neutrophil activation. This substance at a concentration of $100 \mathrm{nmol} / 1$ potentiates polymorphonuclear neutrophil stimulation by formyl-MetLeu-Phe (40) and inhibits superoxide generation at higher concentrations. These effects might depend on the length of polymorphonuclear neutrophil treatment with staurosporine. Combadière et al. reported $125 \%$ $\mathrm{O}_{2}^{-}$production compared to the control (41) while we found a $200 \%$ increase in $\mathrm{O}_{2}^{-}$production by polymorphonuclear neutrophil incubation $10 \mathrm{~min}$ with staurosporine before the addition of formyl-Met-Leu-Phe. Likewise, an increase of phosphatidic acid release was shown by Reinhold et al. (42) and Perianin et al. (43). Recently, Mori et al. (44) have shown that enhancement of superoxide production by staurosporine $100 \mathrm{nmol} / \mathrm{l}$ via phospholipase D activation in formyl-Met-Leu-Phestimulated polymorphonuclear neutrophils was the result of an increase in diacylglycerol production through phosphatidic acid.

Considering the phopsholipase $\mathrm{D}$ activation already described with staurosporine, we hypothesize that the effects of LDL treatment on polymorphonuclear neutrophil phosphoinositide metabolism could be explained by a similar mechanism.
In formyl-Met-Leu-Phe-activated polymorphonuclear neutrophils, phosphatidylcholine is the phospholipase D substrate generating phosphatidic acid which in turn leads to a diacylglycerol release after its dephosphorylation by phosphatidate phosphohydrolase. Rossi et al. have shown that this enzyme was inhibited by propranolol (45). In the same experimental conditions as those used by these authors, we showed an enhancement of $\mathrm{O}_{2}^{-}$generation which is for English et al. (46) correlated to phosphatidic acid release. However, Agwu et al. have shown that polymorphonuclear neutrophil stimulation by formyl-MetLeu-Phe was counteracted by high a propranolol concentration $(5 \mathrm{mmol} / \mathrm{l})$ which inhibited phospholipase $\mathrm{D}(47)$. Under the same experimental conditions, we observed that LDL did not modify the propranolol effect.

In formyl-Met-Leu-Phe-stimulated human neutrophils, protein kinase $\mathrm{C}$-independent activation mechanisms have been suggested and Müller \& Nigam (48) have shown that staurosporine enhances arachidonic acid and platelet activation, and leukotriene $\mathrm{B}_{4}$ release. We have thus tested the activity of niflumic acid, a non-steroidal anti-inflammatory drug, on polymorphonuclear neutrophil activation. According to Abramson et al. (49) various concentrations of niflumic acid inhibited formylMet-Leu-Phe-induced $\mathrm{O}_{2}^{-}$generation in a concentrationdependent manner. Nevertheless, niflumic acid did not inhibit the LDL-induced polymorphonuclear neutrophil oxidative metabolism and even the lowest concentration used $(88.5 \mu \mathrm{mol} / \mathrm{l})$ potentiated an LDL effect, probably by stimulating phospholipase $A_{2}$, which leads to arachidonic acid accumulation.

LDL is able to modify in vitro the polymorphonuclear neutrophil oxidative metabolism either by a direct stimulating effect or by alteration of the polymorphonuclear neutrophil response to formyl-Met-Leu-Phe by an action which could involve phospholipase $\mathrm{D}$ and phospholipase $\mathrm{A}_{2}$ activations.

The LDL structure plays a main role in its action of polymorphonuclear neutrophil functions. LDL modifies cell lipid content, since a concentration-dependent increase in cholesterol level was observed after incubation of polymorphonuclear neutrophil with increasing LDL concentrations. We have previously demonstrated (5) that LDL from hypertriglyceridaemic subjects stimulated the polymorphonuclear neutrophil oxidative metabolism and inhibited polymorphonuclear neutrophil chemotaxis less than LDL from normolipaemic subjects whose composition is different. Moreover, LDL trypsination experiments showed that the lipid moiety is mainly responsible for the described effects of LDL on polymorphonuclear neutrophil migration (5). These observations, added to the fact that the polymorphonuclear neutrophil cholesterol amount increases after the incubation of these cells with increasing LDL concentrations, 
suggest that lipid exchanges between lipoproteins and cell membranes might appear and modify the membrane fluidity. These modifications could alter formyl-MetLeu-Phe receptor expression and affinity. This hypothesis was corroborated upon viewing the alteration of formyl-Met-Leu-Phe binding on polymorphonuclear neutrophils extracted from hyperlipidaemic type IIb patients (50).

In spite of their short half-life, polymorphonuclear neutrophils could be involved in atherogenic states because they display, in their excited state, a great source of free radicals involved in endothelial injuries. LDL are transported into the intimal layer through the endothelium (51) and their concentration in the arterial

\section{References}

1. Steinberg D, Parthasarathy S, Carew TE, Khoo JC, Witztum JL. Beyond cholesterol. Modifications of low-density lipoproteins that increase its atherogenicity. N Engl J Med 1989; 320:915-24.

2. Slyper AH. Low-density lipoprotein density and atherosclerosis. J Am Med Ass 1994; 272:305-8.

3. Terkeltaub R, Curtiss LK, Tenner AJ, Ginsberg MH. Lipoproteins containing apoprotein $B$ are a major regulator of neutrophil responses to monosodium urate crystals. J Clin Invest 1984; 73:1719-30.

4. Ludwig P, Hunninghake D, Hoidal J. Increased leukocyte oxidative metabolism in hyperlipoproteinaemia. Lancet 1982; $14: 348-50$.

5. Bonneau C, Couderc R, Roch-Arveiller M, Giroud JP, Raichvarg D. Effects of low-density lipoproteins on polymorphonuclear leukocyte functions in vitro. J Lipid Mediat Cell Signal $1994 ; 10: 203-12$.

6. Ricevuti G, Mazzone A, Pasotti D, De Servi S, Speccia G. Role of granulocytes in endothelial injury in coronary heart disease in humans. Atherosclerosis 1991; 91:1-14.

7. Harats D, Mulkins MA, Sigal E. A possible role for 15-lipoxygenase in atherogenesis. Trends Cardiovasc Med 1995; $5: 29-36$.

8. Consigny PM. Pathogenesis of atherosclerosis. Am J Roentgenol 1995; 164:553-8.

9. Ward PA. Mechanisms of endothelial cell injury. J Lab Clin Med 1991; 188:421-6.

10. Natarajan V. Oxidants and signal transduction in vascular endothelium. J Lab Clin Med 1995; 125:26-37.

11. Wieland E, Brandes A, Armstrong VW, Oellerich M. Oxidative modification of low-density lipoproteins by human polymorphonuclear leukocytes. Eur J Clin Chem Clin Biochem 1993; 31:725-31.

12. Jackson RL, Ku G, Thomas CE. Antioxydants: a biological defense mechanism for the prevention of atherosclerosis. Med Res Rev 1993; 13:161-82.

13. Kilgore KS, Lucchesi BR. Reperfusion injury after myocardial infarction: the role of free radicals and the inflammatory response. Clin Biochem 1993; 26:359-70.

14. Babior BM. The respiratory burst of phagocytes. J Clin Invest 1984; 73:599-601.

15. Chanock SJ, El Benna J, Smith RM, Babior BM. The respiratory burst oxidase. J Biol Chem 1994; 269:24519-22.

16. Lambeth JD. Activation of the respiratory burst oxidase in neutrophils: on the role of membrane-derived second messengers, $\mathrm{Ca}^{++}$, and protein kinase C. J Bioenerg Biomembr 1988; 20:709-33.

17. Snyderman R, Uhig RJ. Phagocytic cells: stimulus-response coupling mechanisms. In: Gallin JI, Goldstein IM, Snyderman $\mathrm{R}$, editors. Inflammation: basic principles and clinical correlates. New York: Raven Press, 1988:309-23. intima is three times greater than in plasma (52). The polymorphonuclear neutrophils present in the intima may be activated by LDL. Activated neutrophils might produce oxygen free radicals and therefore modify LDL but they are found in small numbers in the atherosclerotic intima (53). However it has been shown in rabbits fed a high cholesterol diet that polymorphonuclear neutrophils were the most numerous cells at the beginning of the atheromateous process, and were soon replaced by monocytes and lymphocytes (54). Therefore it seems particularly interesting to study the interaction between polymorphonuclear neutrophils and lipoproteins during the early stages of atherogenesis in animal models.

18. Cockcroft S. G-Protein-regulated phospholipases C, D and $A_{2}-$ mediated signalling in neutrophils. Biochim Biophys Acta 1992; 1113:135-60.

19. Baggiolini M, Boulay F, Badwey JA, Curnutte JT. Activation of neutrophil leukocytes: chemoattractant receptors and respiratory burst. FASEB J 1993; 7:1004-10.

20. Weingarten R, Bokoch GM. GTP binding proteins and signal transduction in the human neutrophil. Immunol Lett 1990; 26:1-6.

21. Thelen M, Dewald B, Baggiolini M. Neutrophil signal transduction and activation of the respiratory burst. Physiol Rev 1993; 73:797-821.

22. Zenou M, Raichvarg D, Agneray J. Unmodified phagocytosis after periodate treatment of human granulocytes separated by a two-step method using Ficoll-Hypaque and polyvinylic alcohol medium. Biomedicine $1981 ; 35: 166-9$.

23. Johnston RB, Keel BB, Misra HP, Lehmeyer JE, Webb LS, Baehner RL, et al. The role of superoxide anion generation in phagocytic bactericidal activity. J Clin Invest 1975; 55:1357-72.

24. Tissot M, Mathieu J, Mirossay L, Thuret A, Giroud JP. Polyphosphoinositide metabolism in polymorphonuclear cells from healthy and thermally injured rats. Effect of the immunomodulator RU 41740. J Leukoc Biol 1991; 50:607-14.

25. Creba JA, Downes CP, Hawkins PT, Brewster G, Michell RH, Kirk CJ. Rapid breakdown of phosphatidylinositol 4-phosphate and phosphatidylinositol 4,5-bis-phosphate in rat hepatocytes stimulated by vasopressin and other $\mathrm{Ca}^{2+}$-mobilizing hormones. Biochem J 1983; 212:733-47.

26. Poggioli J, Mauger JP, Claret M. Effect of cyclic AMP-dependent hormones and $\mathrm{Ca}^{++}$mobilizing hormones on the $\mathrm{Ca}^{++}$ influx and polyphosphoinositide metabolism in isolated rat hepatocytes. Biochem J 1986; 235:663-9.

27. Downes CP, Michell RH. The polyphosphoinositide phosphodiesterase of erythrocyte membranes. Biochem J 1981; 198:133-40.

28. Berridge MJ, Dawson RMC, Downes CP, Heslop JP, Irvine RF. Changes in the levels of inositol phosphates after agonistdependent hydrolysis of membrane phosphoinositides. Biochem J 1983; 212:473-82.

29. Periani A, Snyderman R. Analysis of calcium homeostasis in activated human polymorphonuclear leucocytes: evidence for two distinct mechanisms for cytosolic calcium. J Biol Chem $1989 ; 264: 1005-9$.

30. Grynkiewicz G, Poenie M, Tsien RY. A new generation of $\mathrm{Ca}^{2+}$ indicators with greatly improved fluorescence properties. J Biol Chem 1985; 260:3440-50.

31. Kopf GS, Woolkalis MJ. ADP-ribosylation of G proteins with pertussis toxin. Methods Enzymol 1991; 195:257-66.

32. Gabig TG, English D, Akard LP, Schell MJ. Regulation of neutrophil NADPH oxidase activation in a cell-free system by 
guanine nucleotides and fluoride. J Biol Chem 1987; 262:1685-90.

33. Omann GM, Porasik-Lowes MM. Graded G-protein uncoupling by pertussis toxin treatment of human polymorphonuclear leukocytes. J Immunol 1991; 146:1303-8.

34. Hallet MB, Lloyds D. Neutrophil priming: the cellular signals that say 'amber' but not 'green'. Immunol Today 1995; $16: 264-8$

35. Block LH, Knorr M, Vogt E, Locher R, Vetter W, Groscurth $P$, et al. Low density lipoprotein causes general cellular activation with increased phosphatidylinositol turnover and lipoprotein catabolism. Proc Natl Acad Sci USA 1988; 85:885-9.

36. Tamaoki T, Nomoto $\mathrm{H}$, Takahashi I, Kato $\mathrm{Y}$, Morimoto $\mathrm{M}$, Tomita F. Straurosporine, a potent inhibitor of phospholipid/ $\mathrm{Ca}^{++}$dependent protein kinase. Biochem Biophys Res Commun 1986; 135:397-402.

37. Nakadate T, Yeng AY, Blumberg PM. Comparison of protein kinase $\mathrm{C}$ functional assays to clarify mechanisms of inhibitor action. Biochem Pharmac 1988; 37:1541-5.

38. Blumberg PM. Complexities of the protein kinase $\mathrm{C}$ pathway. Mol Carcinog 1991; 4:339-44.

39. Badwey JA, Erickson RW, Curnutte JT. Staurosporine inhibits the soluble and membrane-bound protein tyrosine kinases of human neutrophils. Biochem Biophys Res Commun 1991; 178:423-9.

40. Combadiere C, Hakim J, Giroud JP, Perianin A. Staurosporine, a protein kinase inhibitor, up-regulates the stimulation of human neutrophil respiratory burst by $\mathrm{N}$-formyl peptides and platelet activating factor. Biochem Biophys Res Commun 1990; 168: 65-70.

41. Combadiere C, El Benna J, Pedruzzi E, Hakim J, Perianin A. Stimulation of the human neutrophil respiratory burst by formyl peptides is primed by a protein kinase inhibitor, staurosporine. Blood 1993; 82:2890-8.

42. Reinhold SL, Prescott SM, Zimmerman GA, Mc Intyre TM. Activation of human neutrophil phospholipase D by three separable mechanisms. FASEB J 1990; 4:208-14.

43. Perianin A, Combadiere C, Pedruzzi E, Djerdjouri B, Hakim J. Staurosporine stimulates phospholipase D activation in human polymorphonuclear leukocytes. FEBS Lett 1993; 315:33-7.

44. Mori T, Ando M, Takagi K. Staurosporine and its derivatives enhance f-Met-Phe-induced superoxide production via phospholipase D activation in human polymorphonuclear leukocytes. Int J Clin Pharmacol Ther 1994; 32:422-8.

45. Rossi F, Grzeskowiak M, Della Bianca V, Calzetti F, Gandini G. Phosphatidic acid and not diacylglycerol generated by phos- pholipase $\mathrm{D}$ is functionally linked to the activation of the NADPH oxidase by fMLP in human neutrophils. Biochem Biophys Res Commun 1990; 168:320-7.

46. English D, Taylor GS. Divergent effects of propranolol on neutrophil superoxide release: involvement of phosphatidic acid and diacylglycerol as second messengers. Biochem Biophys Res Commun 1991; 175:423-9.

47. Agwu DE, Mc Phail LC, Sozzani S, Bass DA, Mc Call CE. Phosphatidic acid as a second messenger in human polymorphonuclear leukocytes. Effects on activation of NADPH oxidase. J Clin Invest 1991; 88:531 -9.

48. Müller S, Nigam S. Arachidonic acid release and platelet-activating factor formation by staurosporine in human neutrophils challenged with n-formyl peptide. Eur J Pharmcol 1992; 218:251-8.

49. Abramson SB, Leszczynska-Piziak J, Weissman G. Arachidonic acid as a second messenger. Interactions with a GTPbinding protein of human neutrophils. J Immunol 1991; 147:231-6.

50. Bonneau C, Couderc R, Chanu B, Bailleul S, Roch-Arveiller $\mathrm{M}$, Rouffy $\mathrm{J}$, et al. Fonctions des polynucléaires neutrophiles de sujets hypercholestérolémiques. In: Galteau MM, Siest G, Henny J, editors. Biologie Prospective. Comptes rendus du 8ème colloque de Pont-à-Mousson. Paris: John Libbey Eurotext, 1993:549-52.

51. Muller WA. Migration of leukocytes across the vascular intima. Molecules and mechanisms. Trends Cardiovas Med 1995; 5:15-20.

52. Kovanen PT. Atheroma formation: defective control in the intimal round-trip of cholesterol. Eur Heart J 1990; 11 (Suppl E):238-46.

53. Jonasson L, Holm J, Skalli O, Bondjers G, Hansson GK. Regional accumulation of $T$ cells, macrophages, and smooth muscle cells in the human atherosclerotic plaque. Arteriosclerosis 1986; 6:131-8.

54. Kling D, Holzschuh T, Betz E. Recruitment and dynamics of leukocytes in the formation of arterial thickening - a comparative study with normo- and hypercholesterolemic rabbits. Atherosclerosis 1993; 101:79-96.

Received November 6, 1996

Corresponding author: Dr. R. Couderc, Service de Biochimie, Hôpital Tenon, 4 rue de la Chine, F-75020 Paris, France 